\title{
Green Retail Marketing for the Sustainable Development
}

\author{
G. Ravindran, M. Malathy, J. Saranya
}

\begin{abstract}
The term "sustainability" has become the main word for this competitive resource scarce and human desires are endless and this wider divide has raised customers around the world's interest in environmental fortification. The growing worldwide knowledge of the ecological balance has given them more knowledge of the environment. Green products refer to selling products or services by highlighting their environmental benefits. So it is called eco-Marketing or environmental marketing and consumers recognize such brands like organic, eco-friendly, recyclable or sustainable. The green marketing services are financial services, transportation services, medical services, educational institutions and retail services. This study focuses about the retail services in green marketing.
\end{abstract}

Key words: Green marketing, sustainability and retailers

\section{INTRODUCTION}

The green marketing approach includes a wide array of businesses, including product changes and fair trade practices, eco-friendly manufacturing and altered advertising and packaging. Green marketing or environmental marketing includes all actions to create and promote exchanges that fulfill human requirements or wants with minimal adverse environmental impacts. The word green and environmental marketing has taken center stage in latest years and reflects an increasing concern at all levels about the consequences on the physical setting of enhanced consumption. Retailers has to take the lead in green marketing and the one who takes they are leaders in the market industry. In most instances, it is the biggest product marketing channel in their respective goods and particularly energy-using products. These distributors are the main players to reach thousands of customers. This has turned the behavioral plans into people and companies. There's now an age of green goods that react to recycling, non -toxic and the environment. The fresh mantra for green marketers has developed to convince the target audience. Most of the organizations in the whole globe try to decrease the damaging environmental and climatic effects of manufacturing procedures. The reasons for adopting green retail marketing are chances or competitive benefits, CSR, Government pressure, competitive pressure and cost problems.

\section{OBJECTIVES OF THE STUDY}

Revised Manuscript Received on December 16, 2019

G. Ravindran, Dean-Kalasalingam Business school KARE, Mail id: grindran@gmail.com

M. Malathy, Assistant Professor, Department of Commerce, S.I.V.E.T College, Mail id: malathysuresh01@gmail.com

J. Saranya, Assistant Professor, Department of Commerce, Guru Nanak College, Mail id: grindran@gmail.com
- To study the consumer perceptions about green retail products

- To inculcate the buying motives in purchase of green products

- To analyze the impact of retail green products for the sustainable development

\section{GREEN MARKETING CONCEPT}

Green marketing includes the development and promotion, without any adverse environmental consequences, of products and services which fulfill customer demands and require quality, performance, affordable pricing or comfort. People usually want to do the correct thing, so that the green marketing company's challenge and chance is to create it simple. The marketing sector can walk, speak and become the fresh environmental champion. Successful Green marketers will benefit from the benefits of good earnings and an enhanced shareholder value and assist to improve the world in the future.

In the assessment of their effect on the environment and marketers ' dedication to the environment, environmentalist analysts assess products. Environmentally secure goods are endorsed and green signals are received and used on publicity and packaging by businesses. Green marketing is aimed at maintaining the environment.

\subsection{Eliminate the concept of waste}

Inefficiency typically results from waste and pollution. Produce the goods without waste, therefore, instead of waste handling.

\subsection{Reinvest the concept of a product}

Consumables or long-term products should be products. Consumer products can either be consumed or put into the soil without damaging the environment. In a closed loop scheme, durables can be produced, used and returned to the manufacturer.

\subsection{Make prices reflect the cost}

Each product should not just replicate the direct cost of production but also air, water and soil, or at least approximate the real cost of it.

\subsection{Make environmentalism profitable}

Consumers are educated by retailers to realize that market competition should not be between environmentally harmful businesses and those seeking to save them. Green marketing is also known as eco-friendly buying and selling activities. In the late 1980s and early 1990s it became famous. This includes the investigation of beneficial and negative elements of marketing operations relating to pollution, energy decline and non-energy loss. 


\section{CONCEPTUAL FRAMEWORK FOR THE STUDY GREEN MARKETING RETAILING}

Sustainability is no longer limited to few goods producers. Retail unit is also recognizing the significance of go behind the eco-friendly activities. Global warming and reduction of green cover due to unfavorable production processes is rapid and becoming a crucial issue for all countries. Primarily 'going green' was about contribution of eco -friendly and organic goods in stores. But now the focus is on structuring green actions in store operations and also along the supply chain. There is also developing the alertness among retailers about carbon footprints at the production and operations level. Retailers are looking to develop a positive thought on the consumer's mind about their brand.

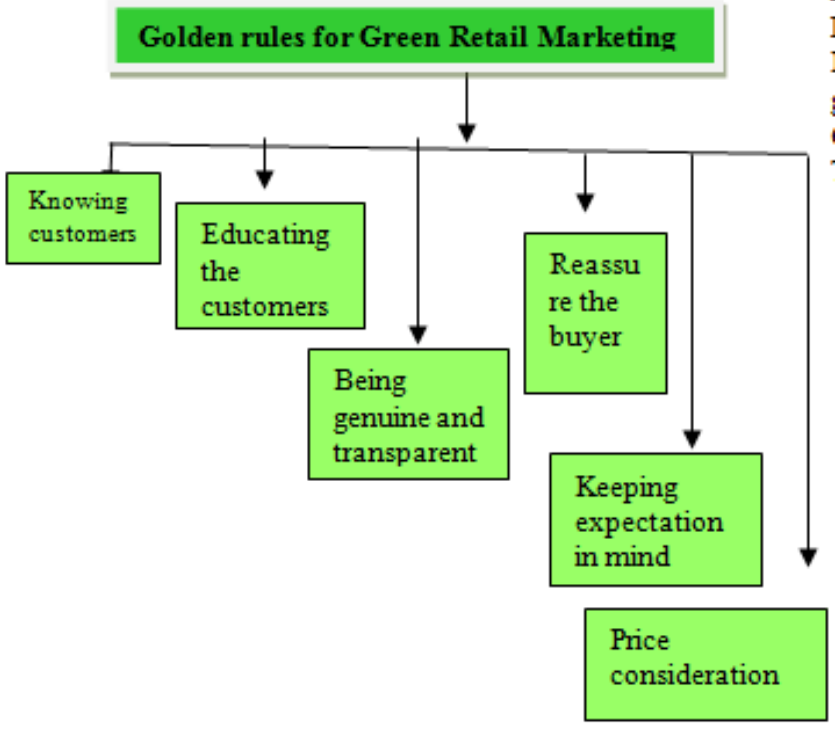

Golden rules for green retail marketing

Knowing customer

Green marketing retailers has to know their customers group to explain about the features of the green product so that the customers will be aware of green products

\section{Educating the customers}

Educating the customers about the product and green marketing retailers has to meet the customers to explain about the usage and benefits of the green products and must know to differentiate with non-green products.

\section{Being genuine and transparent}

Being genuine and transparent to the customers is the one of the golden rule in green marketing that has to be maintained for the long survive in the market in future.

\section{Reassure the buyer}

Green retailers have to reassure green products while selling to the buyer so that trust about the green products will increase among consumers to become regular customers for the specific green product.

\section{Keeping expectation in mind always}

When the trust is created by the green marketing retailers to the consumers because of that the consumer keep expectation in mind about the product to make regular purchase.

\section{Price consideration}

The price consideration is very important for the customers so that it is betterment of maintaining the customer relationship management for selling green product in future. Research Methodology
The research is to find the green marketing products and green retail practices and to create awareness about the green marketing in Chennai

\section{Research Design:}

Descriptive research has been applied as research devise. Sampling techniques:

Simple random sampling technique has been applied, here by way of choosing respondents (retailers) randomly from Chennai. There are ten taluks in Chennai District, a minimum of five respondents from each taluk have been chosen by the researcher.

\section{Data Collection:}

Data gathered through Questionnaire. Primary facts were gathered using Questionnaire. From the total population of Chennai, 56 retailers have been chosen for this study.

Tools and Techniques:

Percentage Analysis Chi Square test Factor analysis

\section{DATA ANALYSIS AND INTERPRETATION}

\subsection{Percentage Analysis}

Table - I

Believe in concept of green marketing

\begin{tabular}{|l|l|l|}
\hline $\begin{array}{l}\text { Believe in } \\
\text { concept of green } \\
\text { marketing }\end{array}$ & Frequency & Percent \\
\hline yes & 33 & 58.9 \\
\hline no & 4 & 7.1 \\
\hline maybe & 19 & 33.9 \\
\hline Total & 56 & 100.0 \\
\hline \multicolumn{2}{|l}{ Source: Primary data }
\end{tabular}

Source: Primary data

Chart - I

Believe in concept of green products

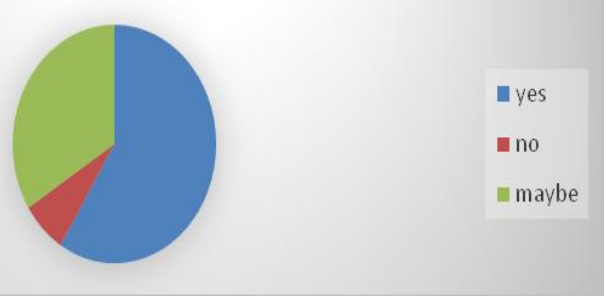

Source: Primary data

\section{Inference}

The above table demonstrates that $58.9 \%$ of the respondents believe in concept of green marketing and 33.9 $\%$ of the respondents opted may be they may believe the green products and $7.1 \%$ of the respondents opted that they doesn't have the belief in green products.

\subsection{Chi Square test}

To study about the perceptions about the concept of green marketing of the respondents and environment protection responsibility

\section{Null hypothesis}

$\mathrm{HO}$ : There is no relationship between the concept of green marketing of the respondents and environment protection responsibility

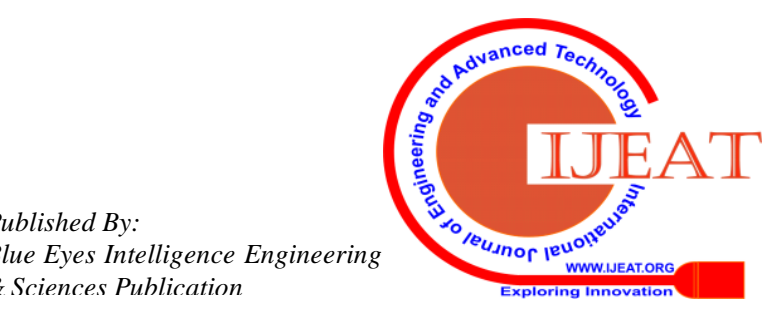




\section{Alternative hypothesis}

H1: There is an relationship between the concept of green marketing of the respondents and environment protection responsibility.

Table - II

Concept of green marketing of the respondents and environment protection responsibility.

\begin{tabular}{|c|c|c|c|c|c|c|}
\hline \multirow{2}{*}{$\begin{array}{l}\text { Concept } \\
\text { of green } \\
\text { marketin } \\
\text { g }\end{array}$} & \multicolumn{5}{|c|}{$\begin{array}{l}\text { Environmental } \\
\text { responsibility }\end{array}$} & \multirow[t]{2}{*}{$\begin{array}{l}\text { Tota } \\
1\end{array}$} \\
\hline & $\begin{array}{l}\text { strongly } \\
\text { agree }\end{array}$ & $\begin{array}{l}\text { agre } \\
\text { e }\end{array}$ & $\begin{array}{l}\text { neutra } \\
1\end{array}$ & \begin{tabular}{|l} 
Dis \\
agre \\
e
\end{tabular} & \begin{tabular}{|l|} 
Strongly \\
Disagre \\
e
\end{tabular} & \\
\hline Yes & 18 & 6 & 2 & 5 & 2 & 33 \\
\hline No & 0 & 0 & 4 & 0 & 0 & 4 \\
\hline Maybe & 6 & 11 & 2 & 0 & 0 & 19 \\
\hline Total & 31 & 17 & 8 & 5 & 2 & 56 \\
\hline
\end{tabular}

Source: Primary data

Table - III Chi-Square Tests

\begin{tabular}{|l|l|l|ll|}
\hline Chi-Square Tests & Valu & df & Asymp. & Sig. \\
\hline Pearson Chi-Square & 36.53 & 4 & .000 \\
\hline Likelihood Ratio & 27.91 & 4 & .000 \\
\hline Linear-by-Linear & 6.737 & 1 & .009 \\
\hline N of Valid Cases & 56 & & & \\
\hline
\end{tabular}

a. 5 cells $(55.6 \%)$ have expected count less than 5 . The minimum expected count is .57.

\section{Source: Compiled from primary data Inference}

From the Table: 3 , it is inferred that $p<0.01$ therefore there is strong evidence to refuse the null hypothesis.

Hence, it is proved there is a relationship between the concept of green marketing of the respondents and environment protection responsibility.

\subsection{Factor analysis}

Table - IV Total Variance Explained

\begin{tabular}{|c|c|c|c|c|c|c|c|}
\hline \multicolumn{8}{|c|}{ Total Variance Explained } \\
\hline \multirow{2}{*}{$\begin{array}{l}\text { Componen } \\
t\end{array}$} & \multicolumn{3}{|c|}{ Initial Eigen values } & \multicolumn{3}{|c|}{$\begin{array}{l}\text { Extraction Sums of } \\
\text { Squared Loadings }\end{array}$} & \multirow{2}{*}{$\begin{array}{l}\text { Rotatio } \\
\text { n Sums } \\
\text { of } \\
\text { Squared } \\
\text { Loading } \\
\text { s } \\
\text { Total }\end{array}$} \\
\hline & $\begin{array}{l}\text { Tota } \\
1\end{array}$ & $\begin{array}{l}\% \text { of } \\
\text { Varia } \\
\text { nce }\end{array}$ & $\begin{array}{l}\text { Cumul } \\
\text { ative } \%\end{array}$ & Total & $\begin{array}{l}\% \text { of } \\
\text { Varianc } \\
\mathrm{e}\end{array}$ & $\begin{array}{l}\text { Cumu } \\
\text { lative } \\
\% \\
\end{array}$ & \\
\hline $\begin{array}{l}\text { Life style \& } \\
\text { personal } \\
\text { belief }\end{array}$ & $\begin{array}{l}4.19 \\
9\end{array}$ & $\begin{array}{l}46.65 \\
2\end{array}$ & 46.652 & 4.199 & 46.652 & $\begin{array}{l}46.65 \\
2\end{array}$ & 3.541 \\
\hline $\begin{array}{l}\text { Impact on } \\
\text { the future }\end{array}$ & $\begin{array}{l}1.28 \\
7\end{array}$ & $\begin{array}{l}14.30 \\
5\end{array}$ & 60.957 & 1.287 & 14.305 & $\begin{array}{l}60.95 \\
7\end{array}$ & 3.208 \\
\hline $\begin{array}{l}\text { Global } \\
\text { warming }\end{array}$ & .936 & $\begin{array}{l}10.39 \\
7\end{array}$ & 71.354 & & & & \\
\hline Quality & .735 & 8.169 & 79.523 & & & & \\
\hline $\begin{array}{l}\text { Enhance } \\
\text { quality of } \\
\text { life }\end{array}$ & .536 & 5.956 & 85.479 & & & & \\
\hline $\begin{array}{l}\text { Environmen } \\
\text { tal } \\
\text { protection } \\
\text { responsibilit } \\
\text { y }\end{array}$ & .495 & 5.504 & 90.983 & & & & \\
\hline
\end{tabular}

\begin{tabular}{|l|l|l|l|l|l|l|l|}
\hline $\begin{array}{l}\text { Future } \\
\text { concerns }\end{array}$ & .393 & 4.365 & 95.348 & & & & \\
\hline $\begin{array}{l}\text { Increase } \\
\text { product } \\
\text { value and } \\
\text { quality }\end{array}$ & .250 & 2.772 & 98.120 & & & & \\
\hline $\begin{array}{l}\text { High } \\
\text { satisfaction }\end{array}$ & .169 & 1.880 & $\begin{array}{l}100.00 \\
0\end{array}$ & & & & \\
\hline Extraction Method: Principal Component Analysis. & \\
\hline $\begin{array}{l}\text { a. When components are correlated, sums of squared loadings cannot be added } \\
\text { to obtain a total variance. }\end{array}$
\end{tabular}

Source: Compiled from primary data

Table - V KMO and Bartlett's Test

\begin{tabular}{|l|l|l|}
\hline \multicolumn{2}{|l|}{ KMO and Bartlett's Test } \\
\hline $\begin{array}{l}\text { Kaiser-Meyer-Olkin } \\
\text { Adequacy. }\end{array}$ & Measure of Sampling & .761 \\
\hline \multirow{3}{*}{$\begin{array}{l}\text { Bartlett's Test of } \\
\text { Sphericity }\end{array}$} & Approx. Chi-Square & 210.4 \\
\cline { 2 - 3 } & df & 36 \\
\cline { 2 - 3 } & Sig. & .000 \\
\hline
\end{tabular}

\section{Source: Compiled from primary data}

\section{Inference}

The KMO index ranges from 0 to 1.0 , reaching 1.0 when every variable is perfectly predicted with no mistake by further variables. With a KMO value of 0.761 , the data falls into the excellent factor analysis range. The Bartlett's test is also important at the uppermost level, indicative of aptness for factor analysis. The various factors towards the level of risk connected with the investment choices were investigated with the aid of factor analysis. The numerous factor which persuade the investment choices are clustered into 9 factors like Life style and personal beliefs, Impact on the future, Global warming/ climate change, quality, Belief that green products enhance quality of life, Environmental protection responsibility, Future concerns regarding climate change/ global warming, Potential increase of product value / quality, and high level of satisfaction.

\section{Suggestions}

$>$ Green products awareness and effectiveness has to be created among customers

$>$ Green products should be priced according to its quality and the quantity

$>$ It should not be more price difference between standard product and green product

$>$ Green product's superiority should be improved than standard goods.

Limitations of the Study

- The data gathered for the study is a small group of retailers with a narrow sample size of 56 .

- Primary facts were taken with the authorization of the retailers.

- Secondary facts were taken with the authentication from the web sources.

- Data gathered from the respondents are based on their outlooks and understanding and which will be forced to create more biased information. 


\section{CONCLUSION}

Eco-friendly buying and selling activities are still in its babyhood stage and there are plenty of studies on green marketing that needs to be done to explore its full potential. The most effective platforms are creating awareness about green marketing in websites, blog, and social media pages. Green retailers have to promote eco-friendly marketing to environment as well as the awareness has to be created among consumers to build an emotional connection with green products to make green efforts a part of brand's story in market industry.

\section{REFERENCES}

1. Priyank Azad, Marketing Management, APH Publishing Corporation, NewDelhi, 2012,p.332.

2. Gupta C.B, Rajan Nair., N, Marketing Management, Sultan Chand and Sons, New Delhi, 2012, P-20.17.

3. Philip Kotler, Gary Armstrong, prafulla Y. Agnihotri, Ehsan ul Haque, Marketing A South Asian Perspective, Dorling Kindersley (India) pvt Ltd, licenses of Pearson education in South Asis, 2011.

4. M.Selva Kumar.M, Ramesh pandi.G, Green Marketing- An Innovative International Business, Procedings of the National Level Conference on International Trade after the Economic Cricis: Challenges and New Opportunities, 2013, p- 108 .

5. Sherlekar, S.A., Marketing Management, Himalaya Publishing House, New Delhi, 2010, P-185

\section{AUTHORS PROFILE}

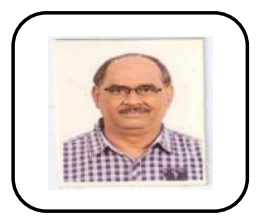

Dr.G.Ravindran M.Com., M.Phil., Ph.D. He is former Director - University Students Advisory Bureau, University of Madras. He was Senate Member and Academic Council Member in University of Madras. He was the Commerce Board Chairman in University of Madras. He has published ten research article in the various reputed journals in national and and international levels. Acting as a Guide for Ph.D Programme in the Madras University, Dravidian University and MS University. He is also acting as a Guide for M.Phil Programme in the Madras University, Alagappa University, Madurai Kamaraj University and Annamalai University. He has presented more than fifty papers in various seminars and conference. He is also acting as a external examiner for Madras University and Alagappa University.

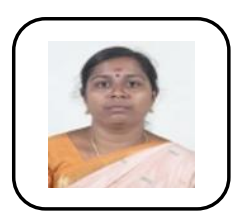

Dr. M. Malathy, M.Com., M.B.A., M.Phil. ,M.F.T., Ph.d, Assistant

Professor, Department of Commerce, S.I.V.E.T College, Chennai, India. She is a member in Indian Accounting Association. She has 16 years of teaching experience both at PG and UG level and her paper was published in 7 international journals and presented 13 papers in state, national and international conferences. She is acting as a research supervisor for M.Phil programme (full-time) for Madras University and part time for many of the reputed universities. Her research areas include Finance and Marketing.

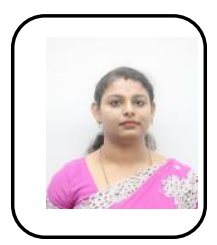

Mrs. Saranya.J, M.Com., MBA, M.Phil., Assistant Professor Department of Commerce (Honours), Guru Nanak College, Chennai, India. She has five years of teaching experience for PG and UG and her paper was published in 11 international journals and presented 7 papers in national and international conferences. She won the best young teaching faculty award in 2018. Her research areas include HR and Finance. 